\title{
ASSOCIATION FOR RADIATION RESEARCH
}

SOME 170 persons attended the seventh meeting $N$ of the Radiation Research Visiting Club held at the Medical Research Council Experimental Radiopathology Research Unit, Hammersmith Hospital, on May 9 and 10. About 100 were present at the open business meeting at which the need for a rather more formal organization was debated under the chairmanship of Prof. F. S. Dainton. This meeting brought to an end the first phase in the exist. ence of the Club, which hitherto has had no rules, no committee, and no subscription, its only existence between meetings having been a list of 'member centres' with some names of individual radiation research workers. The whole responsibility for each meeting has rested on the hosts who have come forward with invitations, and they have been at liberty to arrange the meetings entirely as they wished. The informality of the meetings and the absence of organization appealed to most of those who attended, and many felt very reluctant to start a new scientific society or association. It was generally agreed, however, that the need had become pressing, for two main reasons: the numbers of research workers who had become interested had grown so large that membership on an individual basis was clearly necessary; also, some form of organization was needed to establish and maintain liaison nationally and internationally with bodies having similar or related interests. It was resolved, therefore, that an Association be formed.

The Visiting Club originally sprang from a desire on the part of scientists of different disciplines to meet together in each others' laboratories to discuss topics of mutual interest in the field of radiobiology in which they were working. The meetings of the Club have shown that the subject of radiobiology is broad enough to bring together a group of convenient size. It is probable that other branches of radiation research such as radiation chemistry could do the same. The issue most keenly debated at the recent meeting was whether the organization which the meeting proposed to bring into being should be an Association of people who were meeting primarily on the common ground of radiobiology-with the corollary that similar group organizations would be established for other branches of radiation researchor whether an attempt should be made to establish an organization which would meet the needs of all radiation research workers. As the name of the Association implies, the latter alternative was chosen, and one of the objects of the new Association was defined as being : "To bring together research workers of different disciplines, having a common interest in radiobiology, radiation chemistry and radiation physics".
It was the express wish of those present at this and previous meetings of the Visiting Club that the scientific business of the Association should be "conducted mainly according to the precedent set by meetings of the Radiation Research Visiting Club which have been held before the formation of the Association", and this proviso was incorporated in the constitutional rules which were agreed upon as a minimum operational requirement. From now on, however, the privilege of attending these meetingss will be reserved for members of the Association.

Other constitutional rules were decided on which defined the conditions for eligibility to membership"any person actively interested in the fields covered by the objects of the Association shall be eligible for election to membership" - and the composition of the committee, which everyone agreed should include radiation research workers from varied fields of interest. The first committee, elected for a two-year period, is as follows : chairman, Dr. L. H. Gray ; honorary secretary, Miss T. Alper, Experimental Radiopathology Research Unit, Hammersmith Hospital, Ducane Road, London, W.12; honorary treasurer, Dr. C. L. Smith; ordinary members, Prof. A. Charlesby, Prof. F. S. Dainton, Dr. Alma Howard, Dr. J. F. Loutit, Prof. J. S. Mitchell, Dr. Edith Paterson.

The annual subscription was fixed at $10 \mathrm{~s}$, and it was agreed that anyone who has attended any of the seven meetings of the Radiation Research Visiting Club should qualify for membership without election. Any others wishing to join the Association should be proposed and seconded by members who know them personally. Forms for the purpose may be obtained from the honorary secretary and should be returned by the proposer with accompanying letter of recommendation. It is hoped that the first election of new members will take place at a business meeting which will be held in conjunction with the first scientific meeting of the Association. This will probably take place early in 1959, in Newcastle on Tyne, at the invitation of Prof. J. Weiss. Particulars will be circulated in due course to all who have become members of the Association by the appropriate time.

Most radiation research workers have affiliations with learned societies in their own specialty. The Visiting Club has never duplicated the activities of any learned society, but has set out to bridge the gaps between different disciplines. If, in its larger context, the Association can foster an exchange of knowledge and experience in the same friendly and intimate way as the Club has done, we feel that its future is assured.

L. H. GRAY

Tikvah ALPER

\section{FRITZ LONDON AWARD}

\begin{abstract}
THE fifth International Conference on Low Temperature Physics and Chemistry, held at the University of Wisconsin during August 26-31, 1957, was the occasion of the presentation of the first Fritz London Award. The Award is to be made biennially and carries an honorarium of 1,000 dollars, together with an expense allowance of 500 dollars. The recipient was Dr. N. Kurti, of the Clarendon
\end{abstract}

Laboratory, Oxford, and the texts of the introductory remarks made by Dean F. G. Brickwedde (Pennsylvania State University) and by Prof. J. G. Daunt (Ohio State University), who made the presentation, together with the address entitled "Nuclear Orientation and Nuclear Cooling" delivered by Dr. Kurti, are printed in the March 1958 issue of Physics Today. In a preceding article in the same issue, 